localization of the cerebellum (1885), the physiology of fasting (1889), and human physiology (1898-1903), the latter having been translated into English, German and Spanish. He died on June 23, 1919.

\section{Louis Stromeyer Little}

Мк. Louts Stromeyer Littrue, an eminent surgeon and astronomer, was born in London on November 23, 1840, the third son of Dr. William Little, the orthopædist who gave his name to cerebral diplegia. He was educated at St. Paul's School and at Kiel and Hanover. $\mathrm{He}$ qualified M.R.C.S. in 1862 and the same year became assistant surgeon at the London Hospital, and later was appointed to the National Orthopædic Hospital and St. Mary's Hospital for Women and Children. In 1866, when an epidemic of Asiatic cholera occurred in the East End of London and application was made to the London Hospital for assistance, he took an active and successful part in its treatment by intravenous injection of saline solutions. On the outbreak of the Schleswig-Holstein War in 1864, Little first joined the Prussians, but afterwards joined the Danish forces. In 1869 he went to Shanghai where he soon acquired the best medical practice in the Far East. $\mathrm{He}$ also developed the knowledge of astronomy which he had acquired in London to a remarkable extent, and not only built an observatory at Shanghai, but also established the first telegraphic longitude observed in China by means of telegraphic signals with Nagasaki, 600 miles away on the opposite shore of the Yellow Sea. This achievement gained him the fellowship of the Royal Astronomical Society in 1877. After residence in China for nearly thirty years he returned to England via South Africa, where he was awarded the South African Medal for his services in the Boer War. He died on October 4, 1911.

\section{Prof. Carlo Giacomini}

Prof. Carlo Giacomini, an eminent Italian anatomist and anthropologist, was born at Sale near Alessandria on November 25, 1840. He obtained his medical qualification in 1864 at Turin, where he divided his time between anatomy and clinical medicine until 1880, when he was appointed professor of anatomy and gained a high reputation as a teacher. The classical researches with which he is connected are those on the anatomy and teratology of the brain, his method of preservation of the cerebral convolutions, the anatomy of the negro, and investigations on anomalies of development of the human embryo. He was also co-editor of L'Osservatore. The Museum of Anatomy at Turin owes much to him for its collections. He died at Turin on July 25, 1892.

\section{The Newcomen Society}

ON November 13, at the Iron and Steel Institute, the Newcomen Society held its annual general meeting, and then listened to the reading of two papers. In the report of the Council for the year 1939-40, it was stated that 322 new members have been elected and the membership now stands at 1,512. The majority of the new members are citizens of the United States. Though owing to the stress of war two London meetings were cancelled, a good series of papers were read and many other activities were carried on. The Council sent a chaplet to Handsworth Church on November 15, 1939, to mark the centenary of the death of William Murdoch, and joint action was taken with the Smeatonian Society to place a tablet in the chambers in Gray's Inn occupied by Smeaton during 1783-1793; but the completion of this memorial has had to be deferred. Among the members whose death has been recorded during the year was Mr. L. F. Loree, who is regarded as the founder of the Society in the United States. After the report had been passed, the meeting re-elected Col. C. E. Davies, of New York, for a second year as president. The papers read were respectively by Mr. E. W. Hulme and Dr. H. W. Dickinson, the latter dealing with the work of Henry Cort, the inventor of the puddling process for the manufacture of wrought iron, while Mr. Hulme's paper was entitled "Prehistoric and Primitive Iron Smelting : Part 2, The Crucible Processes of the East". It has been decided owing to the conditions prevailing that no meetings will be held in December and January, but if possible a resumption will be made in February.

\section{Eradication of Bracken}

BRACKEN has become an increasing menace in recent years, and vigorous efforts are being made to find cheap and efficient means for its eradication. Although systematic cutting or crushing can be entirely successful, the process is slow, about eight cuttings at the rate of two a year being required. A more rapid method of destruction is achieved by either broadcasting or spraying with sodium chlorate, but as 2 cwt. per acre is needed the cost (approximately $£ 4$ an acre) is prohibitive. Chlorate, however, is much more toxic when introduced directly into the plant, and Dr. G. H. Bates has devised a mechanical method whereby the chemical can be applied to the cut end of the bracken frond. The chlorate added in this way rapidly kills the aerial portion, and ultimately destroys the underground rhizomes of the plant; only 15-20 lb. of the chemical is required per acre.

The apparatus and method of use are described in Bulletin 14, Rubber and Agriculture Series, published by the British Rubber Publicity Association, 19 Fenchurch Street, London. Bracken crushers or cutting machines which break or bend the stem are not suited to this direct application technique, as unbroken continuity of the vessels is essential for proper penetration of the chlorate; but with hand scythes or machines with reciprocating knives it works well. A small attachment strapped to the worker's belt has been devised for use with a hand scythe. It does not weigh more than $10 \mathrm{lb}$. when filled with solution and needs only be replenished about four times daily. A rubber tube serves as a feed on to a sponge rubber pad, backed by a meta plate which is attached to the scythe blade. The rate of flow can be controlled. A somewhat similar device 
which has proved very efficient has also been constructed for attachment to a motor-scythe, and no special skill is required in its use. Experimental work on the subject is being continued, and it seems possible that given good weather conditions, complete eradiction of bracken may ultimately be obtained after a single cut.

\section{Rationing of Manufacturers' Supplies}

Iт has recently been suggested to us that in placing orders for material or apparatus, an authority for the order should always be quoted in order to secure release of material. In an article on "The Manufacturers' Order Book" by "Sala" which appears in the Electrical Review of November 8, the whole problem raised by questions of priority is discussed. Almost every manufacturer of materials required in the war effort has to decide whether to refuse orders for the time being or to limit the acceptance of orders so as to bring them into line with his estimated output. The manufacturer can obtain but little guidance from his customers as to the urgency of their requirements, for each will rightly demand preference in view of the material being required for urgent Government work. It may also happen that material ordered through the usual trade channels is required for some vitally important part of the war effort and demands priority over orders received direct from Government departments. One way out of the difficulty is for the manufacturer to see that each customer will get a portion of his requirements. This rationing of supplies rarely solves the difficulties. The manufacturer realizes the inadvisability of refusing orders particularly as he generally has no means of authenticating their vital importance in comparison with the uncompleted priority orders still on his books. He feels that the responsibility of limiting or reducing the amounts specified in a consumer's order should not be left to the manufacturer.

\section{Mosquito Control in Great Britain}

THE Ministry of Health has recently published a "Memorandum on Measures for the Control of Mosquito Nuisances in Great Britain" (No. 238, Medicine, 1940) by Lieut.-Col. J. A. Sinton and Mr. P. G. Shute. While mosquitoes may carry malaria in certain circumstances in Britain, as hap. pened during and after the War of 1914-18, it is mainly because of the nuisance caused by the bites that anti-mosquito measures are undertaken in Great Britain. Of the 29 recorded species, eight are so rare or so seldom bite man that they may be considered unimportant from the public health point of view. Anopheles maculipennis is the potential carrier of malaria and during the past twenty-five years more than 500 cases of the disease have been proved to have been locally contracted in almost every instance through its agency. The habits, economy, and means of control of this and other British mosquitoes are dealt with in this memorandum. The information given is up to date and has obviously been carefully collated. If anti-mosquito measures are to be applied effectively and economically the species concerned must be identified and its habits taken into account. Specimens are identified free of charge at the Malaria Laboratory of the Ministry of Health or at the British Museum (Natural History). Once a given species is named the advice given for its control may be followed. The memorandum, it may be added, is to be obtained from H.M. Stationery Office or through any bookseller, price $6 d$. net.

\section{A Parachute Fishing Net}

Dr. J. F. G. WHEELER, director of the Biological Station at Bermuda, has succeeded in designing a workable net in the form of a parachute for catching small deep-sea planktonic organisms. The novel idea of a fishing net without a towing line is adapted from the method used by Prof. Maurice Ewing in his work on the sub-sedimentary rocks beneath the sea. The net fishes upside down. At the top is a fine mesh followed by a wider weave net; it then broadens out to a canvas-like material which has metal 'eyes' punctured into the bottom. From these 'eyes' are attached ropes or bridles. These come down in a $\mathrm{V}$ fashion to a small cord to which is attached a wire receptacle in which is placed a large lump of rock salt. Beneath this are suspended two weights. At the top of the net, and inside it, is a funnel-like pipe leading into a bucket. Affixed to the top of the bucket are a float (a can filled with petrol) and a flag.

The net is nine feet three inches across its mouth and nearly thirty feet long. The two concrete weights total $138 \mathrm{lb}$. The apparatus is easily thrown into the sea. On its downward journey the net swells out and opens in a parachute-like form, retaining its shape on its descent. It catches as it goes down the minute plankton which enters the mouth and passes into the bucket through the funnel. The net touches the bottom. The salt has by this time dissolved (the requisite amount having been roughly calculated) and the weights are released. The closed parachute is then brought to the surface by the float. The net was successfully used at a depth of more than 1,000 fathoms. Its advantages over a tow-net are that it can be handled easily by a small crew in calm weather, and can be left to itself while the boat is elsewhere. Also that the specimens are in better condition when brought to the surface.

\section{The American Museum of Natural History}

THE Americas for the moment are fortunate in being so far removed from the theatre of war as to be able to continue scientific investigation in the field, even though it be only on a restricted scale. During the past summer, the American Museum of Natural History has sent expeditions for zoological and palæontological research to Alaska, Kansas, Texas and Dakota (Science, August 16, 1940). The expedition under Dr. Walter Grainger, curator of palæontology in the Museum, which is exploring the Big Badlands of South Dakota for fossils of the threetoed horse, the pygmy rhinoceros, and cats, especially the sabre-toothed tiger, is accompanied by 